\title{
A NEW OPERATION ON SOFT SETS: EXTENDED SYMMETRIC DIFFERENCE OF SOFT SETS
}

\author{
Nenad S. Stojanović \\ University of Kragujevac, Faculty of Science, \\ Kragujevac, Republic of Serbia, \\ e-mail: nenad.s@kg.ac.rs, \\ ORCID iD: Dhttps://orcid.org/0000-0003-3837-4043
}

DOI: 10.5937/vojtehg69-33655; https://doi.org/10.5937/vojtehg69-33655

FIELD: Mathematics

ARTICLE TYPE: Original scientific paper

\section{Abstract:}

Introduction/purpose: Molodtsov introduced the concept of soft sets as a new mathematical tool for dealing with problems containing uncertainties. In the literature, different kinds of operations of soft sets are defined and used in theory and applications.

Methods: This study is based on the paper "A New Operation on Soft Sets: Extended Difference of Soft Sets" by Sezgin, Ahmad and Mehmood [Journal of New Theory 27 (2019) 33-42].

Results: In this paper, we define a new operation on soft sets, called extended symmetric difference and investigate its relationship between extended symmetric difference and restricted symmetric difference and some other operations of soft sets.

Conclusion: The author believes that the obtained results represent a significant improvement of many known results in the existing literature.

Key words: Soft sets, intersection, union, difference, extended symmetric difference.

\section{Introduction}

Problems with uncertainties are a major issue in many fields such as economics, engineering, environment and so on. One of the theories that deal with uncertainties is the soft set theory which was introduced by Molodtsov in 1999 (Molodtsov, 1999) as a new mathematical tool. In the soft set theory, the problem of setting the membership function does not arise, which makes the theory easily applied to many different fields including game theory, operations research, probability theory, and measurement theory. 
In the literature, different kinds of operations of soft sets are defined and used in the works on the soft set theory and its applications. Well known operations of soft sets and their properties are given by Maji et al. (Maji et al, 2003). However, some of these definitions and their properties have a few gaps, aspointed out by Ali et al. (Aliet al, 2009) and Yang (Yang, 2008). To make some modifications to the operations of soft sets and fill in these gaps, Ali et al. (Ali et al, 2009), Cagman and Enginoglu (Cagman \& Enginoglu, 2010), Pei and Miao (Pei \& Miao, 2005), and Sezgin and Atagun (Sezgin \& Atagun,2011) have made contributions.

In 2011, Sezgin and Atagun (Sezgin \& Atagun, 2011) discussed the fundamental theorems about operations of soft sets i.e; union and intersection of soft sets and other operations, see (Perović et al, 2008). In that paper, they defined union and intersection operations of soft sets both with restricted and extended conditions but defined the difference operation only with the restricted condition. In 2019, Sezgin, Ahmad and Mehmood (Sezgin et al, 2019) defined the extended difference operation.

Here in this paper, we have defined a new operation on soft sets called extended symmetric difference and also proved some of its properties. Moreover, we have also proved the interesting results which show the relationships between extended symmetric difference and other operations. The main objective of this paper is to make the soft set theory more effective and solid by enhancing the conceptual feature of operations on soft sets. This paper is one theoretical study of soft sets.

\section{Preliminaries}

In this section, we recall some basic notions in the soft set theory. Let $U$ be an initial universe set and $E_{U}$ be the set of all possible parameters under consideration with respect to $U$. The power set of $U$ is denoted by $\mathcal{P}(U)$ and $A$ is a subset of $E$. Usually, parameters are attributes, characteristics, or properties of objects in $U$. In what follows, $E_{U}$ (simply denoted by $E$ ) always means the universe set of parameters with respect to $U$, unless otherwise specified.

Molodtsov (Molodtsov, 1999) defined the soft set in the following manner:

Definition 2.1. (Molodtsov, 1999) Let $U$ be an initial universe set, $E$ be a set of parameters, $\mathcal{P}(U)$ be the power set of $U$. A pair $(F, E)$ is called a soft set over $U$, where $F$ is a mapping of $E$ into the set of all subsets of the set $U$. 
In other words, a soft set over $U$ is a parameterized family of subsets of $U$. For $e \in E, F(e)$ may be considered as the set of $e$-elements of the soft set $(F, E)$ or as the set of $e$-approximate elements of the soft set.

Definition 2.2. (Maji et al, 2003) For two soft sets $(F, A)$ and $(G, B)$ over a common universe $U$, we say that $(F, A)$ is a soft subset of $(G, B)$, denoted by $(F, A) \widetilde{\subset}(G, B)$, if it satisfies:

- $A \subset B$,

- for all $e \in A, F(e)$ and $G(e)$ are identical approximations.

Similarly, $(F, A)$ is called a soft superset of $(G, B)$ if $(G, B)$ is a soft subset of $(F, A)$. This relation is denoted by $(F, A) \widetilde{د}(G, B)$.

Definition 2.3. (Maji et al, 2003) Two soft sets $(F, A)$ and $(G, B)$ over a common universe $U$ are called soft equal if $(F, A) \widetilde{\subset}(G, B)$ and $(F, A) \widetilde{\supset}(G, B)$.

Definition 2.4. (Ali et al, 2009) The relative complement of a soft set $(F, A)$ is denoted by $(F, A)^{r}$ and is defined by $(F, A)^{r}=\left(F^{r}, A\right)$, where $F^{r}: A \rightarrow P(U)$ is a mapping given by $F^{r}(e)=U \backslash F(e)$, for all $e \in A$.

Clearly, $(F, A)^{r}=\mathcal{U}_{A} \smile_{\mathcal{R}}(F, A)$ and $\left((F, A)^{r}\right)^{r}=(F, A)$. It is worth noting that in the above definition of complement, the parameter set of the complement $(F, A)^{r}$ is still the original parameter set $A$ (Ali et al, 2009).

Definition 2.5. (Maji et al, 2003) A soft set $(F, A)$ over $U$ is said to be a null soft set denoted by $\Phi$, if for all $e \in A, F(e)=\varnothing$ (null set).

Since some researchers are in some conflict about a null soft set due to its notation, like others (Sezgin \& Atagun, 2011), so we prefer to use $\Phi_{A}$ instead of $\Phi$ for the null soft set of $(F, A)$ as Ali et al. (Ali et al, 2009) used.

Definition 2.6. (Maji et al, 2003) A soft set $(F, A)$ over $U$ is said to be an absolute soft set denoted by $\tilde{A}$, if for all $e \in A, F(e)=U$.

Note that we use the notation $\mathcal{U}_{A}$ instead of $\tilde{A}$ as in (Ali et al, 2009) throughout this paper. 
Definition 2.7. (Ali et al, 2009) Let $(F, A)$ and $(G, B)$ be two soft sets over a common universe $U$ such that $A \cap B \neq \emptyset$. The restricted intersection of $(F, A)$ and $(G, B)$ is denoted by $(F, A) \cap(G, B)$ and is defined as $(F, A)$ ก $(G, B)=(H, C)$, where $C=A \cap B$ and for all $e \in C, H(e)=F(e) \cap G(e)$.

Definition 2.8. (Ali et al, 2009) Let $(F, A)$ and $(G, B)$ be two soft sets over a common universe $U$ such that $A \cap B \neq \emptyset$. The restricted difference of $(F, A)$ and $(G, B)$ is denoted by $(F, A) \smile_{\mathcal{R}}(G, B)$ and is defined as $(F, A) \smile_{\mathcal{R}}(G, B)=(H, C)$, where $C=A \cap B$ and for all $e \in C, H(e)=$ $F(e) \backslash G(e)$.

Definition 2.9. (Ali et al, 2009) Let $(F, A)$ and $(G, B)$ be two soft sets over a common universe $U$ such that $A \cap B \neq \emptyset$. The restricted union of $(F, A)$ and $(G, B)$ is denoted by $(F, A) \cup_{\mathcal{R}}(G, B)$ and is defined as $(F, A) \cup_{\mathcal{R}}(G, B)=(H, C)$, where $C=A \cap B$ and for all $e \in C, H(c)=$ $F(e) \cup G(e)$.

Definition 2.10. (Sezgin \& Atagun, 2011) Let $(F, A)$ and $(G, B)$ be two soft sets over a common universe $U$ such that $A \cap B \neq \emptyset$. The restricted symmetric difference of $(F, A)$ and $(G, B)$ is denoted by $(F, A) \widetilde{\triangle}(G, B)$ and is defined as $(F, A) \widetilde{\triangle}(G, B)=\left((F, A) \cup_{\mathcal{R}}(G, B)\right) \smile_{\mathcal{R}}((F, A)$ ก $(G, B))=(H, C)$, where $C=A \cap B$.

Definition 2.11. (Ali et al, 2009) The extended union of two soft sets $(F, A)$ and $(G, B)$ over a common universe $U$ is the soft set $(H, C)$, where $C=A \cup B$, and for all $e \in C$;

$$
H(e)= \begin{cases}F(e), & e \in A \backslash B, \\ G(e), & e \in B \backslash A, \\ F(e) \cup G(e) & e \in A \cap B .\end{cases}
$$

We write $(F, A) \sqcup_{\mathcal{E}}(G, B)=(H, C)$.

Definition 2.12. (Ali et al, 2009) The extended intersection of two soft sets $(F, A)$ and $(G, B)$ over a common universe $U$ is the soft set $(H, C)$, where $C=A \cup B$, and for all $e \in C$;

$$
H(e)= \begin{cases}F(e), & e \in A \backslash B, \\ G(e), & e \in B \backslash A, \\ F(e) \cap G(e) & e \in A \cap B .\end{cases}
$$

We write $(F, A) \Pi_{\mathcal{E}}(G, B)=(H, C)$. 
Definition 2.13. (Sezginet al, 2019) The extended difference of two soft sets $(F, A)$ and $(G, B)$ over a common universe $U$ is the soft set $(H, C)$, where $C=A \cup B$, and for all $e \in C$;

$$
H(e)= \begin{cases}F(e), & e \in A \backslash B, \\ G(e), & e \in B \backslash A, \\ F(e) \backslash G(e) & e \in A \cap B .\end{cases}
$$

Thus, the relation is shown by $(F, A) \sim_{\mathcal{E}}(G, B)=(H, C)$.

\section{Extended symmetric difference}

For the fundamental properties and theorems related to operations of soft sets such as restricted union, extended union, restricted intersection, extended intersection, restricted difference, extended difference, we refer the readers to the papers Ali et al. (Ali et al, 2009), Cagman and Enginoglu (Cagman \& Enginoglu, 2010), Pai and Miao (Pei \& Miao, 2005), Sezgin and Atagun (Sezgin \& Atagun, 2011) and Sezgin, Ahmad and Mehmood (Sezgin et al, 2019).

Now we are ready to give the definition of extended symmetric difference of soft sets and its basic properties.

Definition 3.1. The extended symmetric difference of two soft sets $(F, A)$ and $(G, B)$ over a common universe $U$ is the soft set $(H, C)$, where $C=$ $A \cup B$, and for all $e \in C$;

$$
H(e)= \begin{cases}F(e), & e \in A \backslash B, \\ G(e), & e \in B \backslash A, \\ F(e) \triangle G(e) & e \in A \cap B .\end{cases}
$$

Thus, the relation is shown by $(F, A) \triangle_{\mathcal{E}}(G, B)=(H, C)$.

Example 1. Let $E$ be the universe set of parameters, $A$ and $B$ be the subsets of $E$ such that

$$
E=\left\{e_{1}, e_{2}, e_{3}, e_{4}, e_{5}, e_{6}\right\}, \quad A=\left\{e_{1}, e_{2}, e_{5}, e_{6}\right\}, \quad B=\left\{e_{1}, e_{4}, e_{5}, e_{6}\right\} .
$$

Let $(F, A)$ and $(G, B)$ be two soft sets over the same universe $U=$ $\left\{h_{1}, h_{2}, h_{3}, h_{4}\right\}$ such that

$$
\begin{gathered}
(F, A)=\left\{\left(e_{1},\left\{h_{1}, h_{3}\right\}\right),\left(e_{2},\left\{h_{1}\right\}\right),\left(e_{5},\left\{h_{2}, h_{4}\right\}\right),\left(e_{6},\left\{h_{1}, h_{4}\right\}\right)\right\}, \\
(G, B)=\left\{\left(e_{1},\left\{h_{4}\right\}\right),\left(e_{4}, U\right),\left(e_{5},\left\{h_{1}, h_{2}, h_{4}\right\}\right),\left(e_{6},\left\{h_{1}, h_{2}\right\}\right)\right\} .
\end{gathered}
$$


Now let us determine $(F, A) \triangle_{\mathcal{E}}(G, B)=(H, A \cup B)$, where

$$
H(e)= \begin{cases}F(e), & e \in A \backslash B, \\ G(e), & e \in B \backslash A, \\ F(e) \triangle G(e) & e \in A \cap B,\end{cases}
$$

for all $e \in A \cup B$. Since $A \backslash B=\left\{e_{2}\right\}, B \backslash A=\left\{e_{4}\right\}$ and $A \cap B=\left\{e_{1}, e_{5}, e_{6}\right\}$, then,

$$
\begin{aligned}
& (F, A) \triangle_{\mathcal{E}}(G, B) \\
& =\left\{\left(e_{2},\left\{h_{1}\right\}\right),\left(e_{4}, U\right),\left(e_{1},\left\{h_{1}, h_{3}, h_{4}\right\}\right),\left(e_{5},\left\{h_{1}\right\}\right),\left(e_{6},\left\{h_{2}, h_{4}\right\}\right)\right\} .
\end{aligned}
$$

Theorem 3.2. The properties of the extended symmetric difference $\left(\triangle_{\mathcal{E}}\right)$ operation
(a) $(F, A) \triangle_{\mathcal{E}} \Phi_{A}=(F, A)$.
(b) $(F, A) \triangle_{\mathcal{E}}(F, A)=\Phi_{A}$.
(c) $(F, A) \triangle_{\mathcal{E}}(G, B)=(G, B) \triangle_{\mathcal{E}}(F, A)$.
(d) $\left((F, A) \triangle_{\mathcal{E}}(G, B)\right) \triangle_{\mathcal{E}}(H, C)=(F, A) \triangle_{\mathcal{E}}\left((G, B) \triangle_{\mathcal{E}}(H, C)\right)$.
(e) $(F, A) \triangle_{\mathcal{E}}(G, B)=\left((F, A) \sim_{\mathcal{E}}(G, B)\right) \cup_{\mathcal{R}}\left((G, B) \sim_{\mathcal{E}}(F, A)\right)$.
(f) $(F, A) \triangle_{\mathcal{E}}(G, B)=\left((F, A) \sqcup_{\mathcal{E}}(G, B)\right) \sim_{\mathcal{E}}((F, A)$ ก $(G, B))$.
(g) $(F, A) \triangle_{\mathcal{E}}(G, B)=\left((F, A) \cup_{\mathcal{R}}(G, B)\right) \sim_{\mathcal{E}}\left((F, A) \Pi_{\mathcal{E}}(G, B)\right)$.

\section{Proof.}

(a) Let $\Phi_{A}=(S, A)$ and $(F, A) \triangle_{\mathcal{E}} \Phi_{A}=(F, A) \triangle_{\mathcal{E}}(S, A)=(H, A)$ where

for all $e \in A \cup A$.

$$
H(e)= \begin{cases}F(e), & e \in A \backslash A, \\ S(e), & e \in A \backslash A, \\ F(e) \triangle S(e) & e \in A \cap A,\end{cases}
$$

Since $S(e)=\emptyset$ for all $e \in A \cup A$, it follows that $F(e) \triangle S(e)=F(e) \triangle$ $\varnothing=F(e)$. This means that $F$ and $H$ are the same mappings. This completes the proof.

(b) Let $(F, A) \triangle_{\mathcal{E}}(F, A)=\Phi_{A}=(H, A)$ where

for all $e \in A \cup A$.

$$
H(e)= \begin{cases}F(e), & e \in A \backslash A, \\ F(e), & e \in A \backslash A, \\ F(e) \triangle F(e) & e \in A \cap A,\end{cases}
$$

Hence, $F(e) \triangle F(e)=\varnothing=H(e)$. This completes the proof.

(c) Let $(F, A) \triangle_{\mathcal{E}}(G, B)=(H, A \cup B)$ where 
for all $e \in A \cup B$.

$$
H(e)= \begin{cases}F(e), & e \in A \backslash B, \\ G(e), & e \in B \backslash A, \\ F(e) \triangle G(e) & e \in A \cap B,\end{cases}
$$

Since,

$$
H(e)=\left\{\begin{array}{ll}
F(e), & e \in A \backslash B, \\
G(e), & e \in B \backslash A, \\
F(e) \triangle G(e) & e \in A \cap B,
\end{array}= \begin{cases}G(e), & e \in B \backslash A, \\
F(e), & e \in A \backslash B, \\
G(e) \triangle F(e) & e \in B \cap A,\end{cases}\right.
$$

for all $e \in A \cup B=B \cup A$, it follows that $(H, B \cup A)=(G, B) \triangle_{\mathcal{E}}(F, A)$.

(d) The proof can be illustrated by similar techniques used to prove (a), (b) and (c), and is therefore omitted.

(e) For the left-hand side of the property, let $(F, A) \triangle_{\mathcal{E}}(G, B)=(H, A \cup B)$, where

$$
H(e)= \begin{cases}F(e), & e \in A \backslash B, \\ G(e), & e \in B \backslash A, \\ F(e) \triangle G(e) & e \in A \cap B,\end{cases}
$$

for all $e \in A \cup B$.

For the right-hand side of the property, let $(F, A) \sim_{\mathcal{E}}(G, B)=(I, A \cup$ $B)$, where

$$
I(e)= \begin{cases}F(e), & e \in A \backslash B, \\ G(e), & e \in B \backslash A, \\ F(e) \backslash G(e) & e \in A \cap B,\end{cases}
$$

for all $e \in A \cup B$. Suppose that $(G, B) \sim_{\mathcal{E}}(F, A)=(J, A \cup B)$, where

$$
J(e)= \begin{cases}G(e), & e \in B \backslash A, \\ F(e), & e \in A \backslash B, \\ G(e) \backslash F(e), & e \in A \cap B .\end{cases}
$$

Assume that, $(I, A \cup B) \cup_{\mathcal{R}}(J, A \cup B)=(K,(A \cup B) \cap(A \cup B))$, where $K(e)=I(e) \cup J(e)$ for all $e \in(A \cup B) \cap(A \cup B)=A \cup B$.

Now, we have

$$
\begin{aligned}
& K(e)= \begin{cases}I(e) \cup J(e), & e \in A \backslash B, \\
I(e) \cup J(e), & e \in B \backslash A, \\
I(e) \cup J(e), & e \in A \cap B,\end{cases} \\
&= \begin{cases}F(e) \cup F(e), & e \in A \backslash B, \\
G(e) \cup G(e), & e \in B \backslash A, \\
(F(e) \backslash G(e)) \cup(G(e) \backslash F(e)), & e \in A \cap B,\end{cases}
\end{aligned}
$$


for all $e \in(A \cup B) \cup(A \cup B)=A \cup B$. It shows that $H$ and $K$ are the identical mapping when we are assuming the attributes of operations about the set theory. Hence the proof is completed.

(f) For the left-hand side of the property, let $(F, A) \triangle_{\mathcal{E}}(G, B)=(H, A \cup B)$, where

$$
H(e)= \begin{cases}F(e), & e \in A \backslash B, \\ G(e), & e \in B \backslash A, \\ F(e) \triangle G(e), & e \in A \cap B,\end{cases}
$$

for all $e \in A \cup B$. For the right-hand side of the property, let $(F, A) \sqcup_{\mathcal{E}}(G, B)=(I, A \cup B)$, where

$$
I(e)= \begin{cases}F(e), & e \in A \backslash B, \\ G(e), & e \in B \backslash A, \\ F(e) \cup G(e), & e \in A \cap B,\end{cases}
$$

for all $e \in A \cup B$. And suppose that $(G, B) \cap(F, A)=(J, A \cap B)$, where $J(e)=A(e) \cap B(e)$ for all $e \in A \cap B$.

Assume that, $(I, A \cup B) \sim_{\mathcal{E}}(J, A \cap B)=(K,(A \cup B) \cup(A \cap B))$, where

$$
K(e)=\left\{\begin{array}{ll}
I(e), & e \in(A \cup B) \backslash(A \cap B), \\
J(e), & e \in(A \cap B) \backslash(A \cup B), \\
I(e) \bigvee(e), & e \in(A \cup B) \cap(A \cap B),
\end{array}= \begin{cases}I(e), & e \in A \backslash B, \\
I(e), & e \in B \backslash A, \\
J(e), & e \in \emptyset, \\
I(e) \bigvee(e), & e \in A \cap B,\end{cases}\right.
$$

i.e.

$$
\begin{array}{r}
K(e)= \begin{cases}F(e), & e \in A \backslash B, \\
G(e), & e \in B \backslash A, \\
(F(e) \cup G(e)) \backslash(F(e) \cap G(e)), & e \in A \cap B,\end{cases} \\
\quad= \begin{cases}F(e), & e \in A \backslash B, \\
G(e), & e \in B \backslash A, \\
F(e) \triangle G(e), & e \in A \cap B,\end{cases}
\end{array}
$$

for all $e \in(A \cup B) \cup(A \cap B)=A \cup B$. This leads that $H$ and $K$ are the identical mapping. Hence this completes the proof.

(g) For the left-hand side of the property, let $(F, A) \triangle_{\mathcal{E}}(G, B)=(H, A \cup B)$, where

for all $e \in A \cup B$.

$$
H(e)= \begin{cases}F(e), & e \in A \backslash B \\ G(e), & e \in B \backslash A \\ F(e) \triangle G(e), & e \in A \cap B\end{cases}
$$

For the right-hand side of the property, let $(G, B) \cup_{\mathcal{R}}(F, A)=(I, A \cap$ $B)$, where $I(e)=A(e) \cup B(e)$ for all $e \in A \cap B$. 
And suppose that $(F, A) \Pi_{\mathcal{E}}(G, B)=(J, A \cup B)$, where

for all $e \in A \cup B$.

$$
J(e)= \begin{cases}F(e), & e \in A \backslash B, \\ G(e), & e \in B \backslash A, \\ F(e) \cap G(e), & e \in A \cap B,\end{cases}
$$

Assume that, $(I, A \cap B) \sim_{\mathcal{E}}(J, A \cup B)=(K,(A \cap B) \cup(A \cup B))$, where

$$
K(e)=\left\{\begin{array}{ll}
I(e), & e \in(A \cap B) \backslash(A \cup B), \\
J(e), & e \in(A \cup B) \backslash(A \cap B), \\
I(e) \bigvee(e), & e \in(A \cap B) \cap(A \cup B),
\end{array}= \begin{cases}I(e), & e \in \emptyset, \\
J(e), & e \in A \backslash B, \\
J(e), & e \in B \backslash A, \\
I(e) \bigvee(e), & e \in A \cap B,\end{cases}\right.
$$
i.e.

$$
\begin{array}{r}
K(e)= \begin{cases}F(e), & e \in A \backslash B, \\
G(e), & e \in B \backslash A, \\
(F(e) \cup G(e)) \backslash(F(e) \cap G(e)), & e \in A \cap B,\end{cases} \\
= \begin{cases}F(e), & e \in A \backslash B, \\
G(e), & e \in B \backslash A, \\
F(e) \triangle G(e), & e \in A \cap B,\end{cases}
\end{array}
$$

for all $e \in(A \cup B) \cup(A \cap B)=A \cup B$.

This leads that $H$ and $K$ are the identical mapping.

Hence this completes the proof.

Now we will illustrate Theorem 3.2.(parts (e) and (f)) with a corresponding example.

Example 2. Let $E$ be the universe set of parameters, $A$ and $B$ be the subsets of $E$ such that

$$
E=\left\{e_{1}, e_{2}, e_{3}, e_{4}, e_{5}, e_{6}\right\}, \quad A=\left\{e_{1}, e_{2}, e_{5}, e_{6}\right\}, \quad B=\left\{e_{1}, e_{4}, e_{5}, e_{6}\right\} .
$$

Let $(F, A)$ and $(G, B)$ be two soft sets over the same universe $U=$ $\left\{h_{1}, h_{2}, h_{3}, h_{4}\right\}$ such that

$$
\begin{gathered}
(F, A)=\left\{\left(e_{1},\left\{h_{1}, h_{3}\right\}\right),\left(e_{2},\left\{h_{1}\right\}\right),\left(e_{5},\left\{h_{2}, h_{4}\right\}\right),\left(e_{6},\left\{h_{1}, h_{4}\right\}\right)\right\}, \\
(G, B)=\left\{\left(e_{1},\left\{h_{4}\right\}\right),\left(e_{4}, U\right),\left(e_{5},\left\{h_{1}, h_{2}, h_{4}\right\}\right),\left(e_{6},\left\{h_{1}, h_{2}\right\}\right)\right\} .
\end{gathered}
$$

Now let us determine $(F, A) \triangle_{\mathcal{E}}(G, B)=(H, A \cup B)$, where

for all $e \in A \cup B$.

$$
H(e)= \begin{cases}F(e), & e \in A \backslash B \\ G(e), & e \in B \backslash A, \\ F(e) \triangle G(e) & e \in A \cap B\end{cases}
$$

Since $A \backslash B=\left\{e_{2}\right\}, B \backslash A=\left\{e_{4}\right\}$ and $A \cap B=\left\{e_{1}, e_{5}, e_{6}\right\}$, then, 
$(F, A) \triangle_{\mathcal{E}}(G, B)$

$=\left\{\left(e_{2},\left\{h_{1}\right\}\right),\left(e_{4}, U\right),\left(e_{1},\left\{h_{1}, h_{3}, h_{4}\right\}\right),\left(e_{5},\left\{h_{1}\right\}\right),\left(e_{6},\left\{h_{2}, h_{4}\right\}\right)\right\}$.

On the other side, we can easily determine that it is and

$\left.\left((F, A) \sim_{\mathcal{E}}(G, B)\right)=\left\{\left(e_{2},\left\{h_{1}\right\}\right),\left(e_{4}, U\right),\left(e_{1},\left\{h_{1}, h_{3}\right\}\right),\left(e_{5}, \emptyset\right\}\right),\left(e_{6},\left\{h_{4}\right\}\right)\right\}$,

$\left((G, B) \sim_{\mathcal{E}}(F, A)\right)=\left\{\left(e_{2},\left\{h_{1}\right\}\right),\left(e_{4}, U\right),\left(e_{1},\left\{h_{4}\right\}\right),\left(e_{5},\left\{h_{1}\right\}\right),\left(e_{6},\left\{h_{4}\right\}\right)\right\}$.

Based on Definition 2.9. we have that

$\left((F, A) \sim_{\mathcal{E}}(G, B)\right) \cup_{\mathcal{R}}\left((G, B) \sim_{\mathcal{E}}(F, A)\right)$

$=\left\{\left(e_{2},\left\{h_{1}\right\}\right),\left(e_{4}, U\right),\left(e_{1},\left\{h_{1}, h_{3}, h_{4}\right\}\right),\left(e_{5},\left\{h_{1}\right\}\right),\left(e_{6},\left\{h_{2}, h_{4}\right\}\right)\right\}$.

Therefore, $(F, A) \triangle_{\mathcal{E}}(G, B)=\left((F, A) \sim_{\mathcal{E}}(G, B)\right) \cup_{\mathcal{R}}\left((G, B) \sim_{\mathcal{E}}(F, A)\right)$.

Similarly, we can easily determine that it is

$\left((F, A) \sqcup_{\mathcal{E}}(G, B)\right)$

$=\left\{\left(e_{2},\left\{h_{1}\right\}\right),\left(e_{4}, U\right),\left(e_{1},\left\{h_{1}, h_{3}, h_{4}\right\}\right),\left(e_{5},\left\{h_{1}, h_{2}, h_{4}\right\}\right),\left(e_{6},\left\{h_{1}, h_{2}, h_{4}\right\}\right)\right\}$,

and

$((F, A) \cap(G, B))=\left\{\left(e_{1}, \emptyset\right),\left(e_{5},\left\{h_{2}, h_{4}\right\}\right),\left(e_{6},\left\{h_{1}\right\}\right)\right\}$.

Based on Definition 2.13. we have that

$\left((F, A) \sqcup_{\mathcal{E}}(G, B)\right) \sim_{\mathcal{E}}((F, A)$ ก $(G, B))$

$=\left\{\left(e_{2},\left\{h_{1}\right\}\right),\left(e_{4}, U\right),\left(e_{1},\left\{h_{1}, h_{3}, h_{4}\right\}\right),\left(e_{5},\left\{h_{1}\right\}\right),\left(e_{6},\left\{h_{2}, h_{4}\right\}\right)\right\}$.

Therefore, $(F, A) \triangle_{\mathcal{E}}(G, B)=\left((F, A) \sqcup_{\mathcal{E}}(G, B)\right) \sim_{\mathcal{E}}((F, A)$ ก $(G, B))$.

\section{Conclusion}

In this paper, we have illustrated a brief analytical review of operations of soft sets. We have defined the extended symmetric difference of soft sets and also proved some of its properties. Moreover, we have shown the relationship between extended symmetric difference and some other operations of soft sets.

\section{References}

Ali, M.I., Feng, F., Liu, X., Min, W.K. \& Shabir, M. 2009. On some new operations in soft set theory. Computers \& Mathematics with Applications, 57(9), pp.1547-1553. Available at: https://doi.org/10.1016/j.camwa.2008.11.009.

Cagman, N. \& Enginoglu, S. 2010. Soft set theory and uni-int decision making. European Journal of Operational Research, 207(2), pp.848-855. Available at: https://doi.org/10.1016/j.ejor.2010.05.004.

Maji, P.K., Biswas, R. \& Roy, A.R. 2003. Soft set theory. Computers \& Mathematics with Applications, 45(4-5), pp.555-562. Available at: https://doi.org/10.1016/S0898-1221(03)00016-6.

Molodtsov, D. 1999. Soft set theory First results. Computers \& Mathematics with Applications, 37(4-5), pp.19-31. Available at: https://doi.org/10.1016/S08981221(99)00056-5. 
Pei, D. \& Miao, D. 2005. From soft sets to information systems. In: 2005 IEEE International Conference on Granular Computing, Beijing, China, 2, pp.617-621, July 25-27. Available at: https://doi.org/10.1109/GRC.2005.1547365.

Perović, A., Jovanović, A. \& Veličković, B. 2008. Teorija skupova matematička teorija beskonačnosti. Belgrade: University of Belgrade, Faculty of Mathematics (in Serbian) [online]. Available at: http://elibrary.matf.bg.ac.rs/handle/123456789/473?locale-attribute=en [Accessed: 20 August 2021]. ISBN: 978-86-7589-058-4.

Sezgin, A., Ahmad, S. \& Mehmood, A. 2019. A New Operation on Soft Sets: Extended Difference of Soft Sets. Journal of New Theory, 27, pp.33-42 [online]. Available at: https://dergipark.org.tr/en/pub/jnt/issue/43609/535589 [Accessed: 20August 2021].

Sezgin, A. \& Atagun, A.O. 2011. On operations of soft sets. Computers \& Mathematics with Applications, 61(5), pp.1457-1467. Available at:https://doi.org/10.1016/j.camwa.2011.01.018.

Yang, C-F. 2008. A note on "Soft Set Theory" [Comput. Math. Appl. 45 (45) (2003) 555-562]. Computers \& Mathematics with Applications, 56(7), pp.1899-1900. Available at: https://doi.org/10.1016/j.camwa.2008.03.019.

\section{НОВАЯ ОПЕРАЦИЯ НАД МЯГКИМИМНОЖЕСТВАМИ: РАСШИРЕННАЯ СИММЕТРИЧЕСКАЯ РАЗНОСТЬ МЯГКИХ МHOЖЕСТВ}

Ненад С. Стоянович

Крагуевацкий университет, естественно-математический фракультет,

г. Крагуевац, Республика Сербия

РУБРИКА ГРНТИ: 27.00.00 МАТЕМАТИКА:

27.17.00 Алгебра;

27.17.21 Структуры

ВИД СТАТЬИ: оригинальная научная статья

Резюме:

Введение/цель: Д.А. Молодцов представил концепцию мягких множеств в качестве нового математического инструмента для решения задач, содержащих неопределенности. В литературе определены различные виды операций над мягкими множествами, которые используются в теории и на практике.

Методы: Данная статья основана на исследовании Сезгина, Ахмада и Мехмуда "Новая операция над мягкими множествами: расширенная разность мягких множеств» [Journal of New Theory 27 (2019) 33-42].

Результаты: В данной статье представлена новая операция над мягкими множествами, называемая расширенной 
симметрической разностью, а также результаты исследования взаимосвязи между расширенной симметрической разностью и ограниченной симметрической разностью и некоторыми другими операциями мягких множеств.

Выводы: Aвтор считает, что полученные им результаты представляют значительный вклад в исследуюмую область.

Ключевые слова: мягкие множества, пересечение, объединение, разность, расширенная симметрическая разность.

\section{НОВА ОПЕРАЦИЈА СОФТ СКУПОВА: ЊИХОВА ПРОШИРЕНА} СИМЕТРИЧНА РАЗЛИКА

Ненад С. Стојановић

Универзитет у Крагујевцу, Природно-математички фракултет, Крагујевац, Република Србија

\section{ОБЛАСТ: математика}

ВРСТА ЧЛАНКА: оригинални научни рад

\section{Сажетак:}

Увод/циљ: Молодсов је представио концепт софрт скупа као ново математичко средство за решавање проблема у којима се јавља неизвесност. У литератури су различите врсте операција софрт скупова дефинисане и коришћене у теорији и различитим облицима примена.

Meтоде: Овај рад заснован је на раду „Нова операција софтm скупова: проширена разлика софт скупова" аутора Сезгина, Aхмада и Mехмуда [Journal of New Theory 27 (2019) 33-42].

Резултати: Дефинисана је нова операција софрт скупова, која се назива проширена симетрична разлика. Истражена је веза између проширене и ограничене симетричне разлике и неких других операција софрт скупова.

Закључак: Аутор верује да добијени резултати представљају значајан допринос досадашњим познатим резултатима.

Кључне речи: софт скупови, пресек, унија, разлика, проширена симетрична разлика.

Paper received on / Дата получения работы / Датум пријема чланка: 23.08.2021. Manuscript corrections submitted on / Дата получения исправленной версии работы / Датум достављања исправки рукописа: 03.10.2021.

Paper accepted for publishing on / Дата окончательного согласования работы / Датум коначног прихватања чланка за објављивање: 04.10.2021. 
(C) 2021 The Author. Published by Vojnotehnički glasnik / Military Technical Courier (www.vtg.mod.gov.rs, втг.мо.упр.срб). This article is an open access article distributed under the terms and conditions of the Creative Commons Attribution license (http://creativecommons.org/licenses/by/3.0/rs/).

(c) 2021 Автор. Опубликовано в «Военно-технический вестник / Vojnotehnički glasnik / Military Technical Courier» (www.vtg.mod.gov.rs, втг.мо.упр.срб). Данная статья в открытом доступе и распространяется в соответствии с лицензией «CreativeCommons» (http://creativecommons.org/licenses/by/3.0/rs/)

(C) 2021 Аутор. Објавио Војнотехнички гласник / Vojnotehnički glasnik / Military Technical Courier (www.vtg.mod.gov.rs, втг.мо.упр.срб). Ово је чланак отвореног приступа и дистрибуира се у складу са CreativeCommonslicencom (http://creativecommons.org/licenses/by/3.0/rs/). 